\title{
Effects of Dietary Supplementation with N-Acetyl Cysteine, Acetyl-L-Carnitine and S-Adenosyl Methionine on Cognitive Performance and Aggression in Normal Mice and Mice Expressing Human ApoE4
}

\author{
Amy Chan · Thomas B. Shea
}

Published online: 13 February 2008

(C) Humana Press 2008

Erratum to: Neuromol Med

DOI 10.1007/s12017-007-8005-y

The first author was mistakenly omitted from the original publication. The correct authorship is

Amy Chan

Thomas B. Shea

The online version of the original article can be found under doi:10.1007/s12017-007-8005-y.

\footnotetext{
A. Chan · T. B. Shea $(\varangle)$

Center for Cellular Neurobiology \& Neurodegeneration

Research, University of Massachusetts Lowell,

Lowell, MA 01854, USA

e-mail: Thomas_shea@uml.edu
} 